ETHICS CHALLENGES IN FORENSIC PSYCHIATRY AND PSYCHOLOGY PRACTICE 



\section{ETHICS CHALLENGES IN FORENSIC PSYCHIATRY AND PSYCHOLOGY PRACTICE}

Edited by Ezra E. H. Griffith 
COLUMBIA UNIVERSITY PRESS

Publishers Since 1893

New York Chichester, West Sussex

cup.columbia.edu

Copyright (C) 2018 Columbia University Press

All rights reserved

Library of Congress Cataloging-in-Publication Data

Names: Griffith, Ezra E. H., 1942- editor.

Title: Ethics challenges in forensic psychiatry and psychology practice / edited by Ezra E. H. Griffith.

Description: New York : Columbia University Press, [2017] | Includes bibliographical references and index.

Identifiers: LCCN 2017033084 (print) | LCCN 2017033900 (ebook) | ISBN 9780231544849 (e-book) | ISBN 9780231183307 (cloth : alk. paper)

Subjects: | MESH: Forensic Psychiatry-ethics | Criminal Psychology-ethics | Decision Making-ethics | United States

Classification: LCC RA1148 (ebook) | LCC RA1148 (print) | NLM W 740 | DDC 174.2/9415-dc23

LC record available at https://lccn.loc.gov/2017033084

Columbia University Press books are printed on permanent and durable acid-free paper.

Printed in the United States of America

Cover design: Noah Arlow 
To Madelon V. Baranoski and John L.

Young, who taught me much about

forensic ethics

And to Chester Middlebrook Pierce, a

friend and mentor 
